\title{
Eurocentrism. An editorial
}

\author{
H. L. WES S E L IN G
}

Netherlands Institute for Advanced Study, Meijboomlaan,1, NL-2242 PR

Wassenaar, The Netherlands. E-mail: h.l.wesseling@nias.knaw.nl

Africa is a European invention. When the Romans finally defeated Carthage, they turned the place into a province and called it Africa. Originally this referred only to a small part of Tunisia and Algeria, but it later became the name of the entire continent. The same happened to Asia, another province of the Roman Empire, in what is now called the Near East. The names of the two other continents demonstrate even more obviously their European origins: America was named after an Italian traveller - and not even Columbus! - and the term Australia comes from the fact that European voyagers who had some vague idea about the existence of this continent but knew nothing about it, called it 'The Unknown Southland', Terra australis incognita.

Thus, these names, consciously - or rather unconsciously, as is the case with terms like the Near East, Non-Western Studies, Overseas History etc - are all witness to the Eurocentric bias in our world view. The same is true for history. History as we know it in its modern scientific form, is a European invention. It was developed in the West in the 19th century. It is characterized by what is called 'the historical method' (chronology, philology, textual criticism, hermeneutics), as well as a particular type of historical thinking. Awareness of the uniqueness of events, the notion of development and succession over time, but also the notion that each period has a specific character with its own values and standards, are characteristic of this thinking. The German historical school played a major role in this development, which is why some of the most famous historical notions are still best known in their German form: Verstehen, Zeitgeist etc.

The historical interpretation that resulted from this was extremely Eurocentric. Weltgeschichte, in fact, came down to European history, for, in the framework of general history, non-European peoples played no role. In the 19th century, the European approach to Asian history was increasingly dominated by feelings of European superiority and a conviction of Asian backwardness. Their supposed backwardness was a fairly recent phenomenon, since European historians and philosophers had traditionally shown a great respect for the ancient civilizations of Asia. Asia was considered as the continent where the cradle of civilization had once stood. But true as it may be that the light of civilization had originally come from the East (ex oriente lux), according to European thinkers since then there had been no development and thus no history. To quote Hegel: Asian history is 'for the most part, really unhistorical, for it is only the repetition of the same majestic ruin', and: 'China and India lie, as it were, still outside the World's History'. ${ }^{1}$

Hegel had, of course, a great influence on Karl Marx and Marx also concluded that Asia 
has no history in the Western sense of the word. In an article of 1853 on 'The future results of British rule in India' he stated: 'Indian society has no history at all, at least no known history. What we call its history, is but the history of the successive invaders who founded their empires on the passive basis of that unresisting and unchanging society'. And nearly ten years later on China: 'The Oriental empires always show an unchanging social infrastructure coupled with unceasing change in the persons and tribes who manage to ascribe to themselves the political superstructure'. ${ }^{2}$

The opinions on Africa were even more categorical. Here there were no ideas about 'the cradle of civilization' or 'the light that once came from the East'. Africa was seen as an ahistorical continent and the African people as a people without civilization and thus without history. The most famous formulation of this judgement is to be found in the Jena Lectures given by Hegel in 1830-31 and published as the Philosophy of History. Here he wrote: 'At this point we leave Africa, not to mention it again. For it is no historical part of the World; it has no movement or development to exhibit (...). What we properly understand by Africa is the Unhistorical Undeveloped Spirit, still involved in the conditions of mere nature, which had to be presented here only as being on the threshold of the World's history'. ${ }^{3}$ Again, the writings of Karl Marx reflect the same line of thought. There is no doubt however that such opinions were by no means a monopoly of Marxist historians. Indeed they never had been. Adam Smith, for example, wrote in The Wealth of Nations: 'Africa (...) as well as several of the countries comprehended under the general name of the East Indies, are inhabited by barbarous nations'. To be true, he also remarked: 'But those nations were by no means so weak and defenceless as the miserable and helpless Americans (...) ${ }^{4}$ These Americans, of course, were not the European colonists but the 'Indians'. This line of thought was continued until very recently. A late echo of it can be found in the work of a Hungarian Marxist historian of Africa, Endre Sik, who wrote in 1966: 'Prior to their encounter with Europeans the majority of African peoples still lived a primitive, barbaric life, many of them even on the lowest level of barbarism. (...) Therefore it is unrealistic to speak of their "history" - in the scientific sense of the word - before the appearance of the European invaders'. 5 Again, this was by no means an exclusively Marxist way of thinking. Just one year before Sik's book appeared, the Regius Professor of Modern History at Oxford - and by no means a Marxist - H. R. Trevor-Roper, compared the histories of Britain and Africa, describing the latter as being little more than 'the unrewarding gyrations of barbarous tribes in picturesque but irrelevant quarters of the globe'.

How things have changed since the 1960s! No sensible person would argue any more that African history does not exist, not even in Oxford. The development of African history has been spectacular. Perhaps it has been the most vivid, dynamic and innovative field of history since the emergence of the new social and economic history in the 1920s and 1930s. One could argue that the Journal of African History has been the most innovative journal since the founding of the French journal of the Annales in 1929. Indeed, the two developments are, to a certain extent, comparable. Social historians, such as those of the Annales and others, began to ask questions that had not been asked before and of which no mention has been made in traditional sources. New sources had to be discovered and new techniques developed to re-examine old sources in a new light. The same situation existed with African history. Sources are scarce, and the very scarcity of sources has given an enormous stimulus to the development 
of new techniques and methods. The past had to be investigated with other means. Anthropology has also played a major role in developing African history.

The great leap forward took place at an astonishing speed. In the mid-1950s, not one of the major postgraduate institutions in the United States (Harvard, Princeton, Chicago, Berkeley, Columbia) offered courses in African history. By the late 1970s there were already 600 professional African historians in the USA. ${ }^{7}$ Next to the Americans, a major role was played by British historians. The Journal of African History - the first issue of which appeared in 1960 - was, as Terence Ranger has said, 'the combined manifesto, charter, programme and shop-window for the field'. ${ }^{8}$ Oliver and Fage's Short History of Africa sold several hundred thousand copies and is probably the single most influential book on African history. Soon, however, the Africans took over the leading role themselves. The UNESCO History of Africa is essentially an achievement of African historians.

The development of an autonomous (= non-Eurocentric) approach to Asian history had taken place earlier. The official British history writing about India was strongly Anglocentric. As Nehru once remarked about the British: 'Real history for them begins with the advent of the Englishman to India; all that went before it is in some mystic kind of way a preparation for this divine consummation'. ${ }^{9}$ Already in the middle of the 19th century, however, as a reaction to the rather condescending approach of the colonial historians, Indian historians developed their own historiography, and in the late 19th century the rise of the nationalist movement gave a strong impetus to this so that by the 1920s and 1930s there existed a considerable group of professional historians. When independence came in 1947, Indian professional historiography was already in a strong position.

In Indonesia, on the contrary, there were practically no professional Indonesian historians before independence. Here, however, the question of Eurocentrism had already been approached in the 1930s by a Dutch colonial civil servant, J.C. van Leur, in his dissertation about early Asian trade, which was published in 1934. He reacted against the exclusively colonial approach, which constituted a distorted perspective and ignored vast areas of historical reality. Most historians, he wrote, see the Asiatic world through the eyes of the Dutch ruler: 'from the deck of the ship, the ramparts of the fortress, the high gallery of the trading house'. ${ }^{10}$ He successfully tried to remedy this view. Even more fundamentally, he also questioned the periodization of history and the place in it allotted to Asia. His ideas were rediscovered in the 1950s and have been very influential in the rethinking of Asian history in the early modern period.

In retrospect, much of the debate about the possibilities and impossibilities of, and the similarities and dissimilarities between, western and non-western history, looks rather futile. Today everybody accepts that Africans and Asians have their own history, and that it is as rich and interesting as that of Europe. The question, however, is whether we can stop here and simply consider world history as the sum of a great number of autonomous regional, national or even continental histories.

Most historians would agree that we should try to do more and study how, in one way or another, these various civilizations have become interconnected, how the world situation of today has come into being. Therefore, the real challenge is now to offer a non-Eurocentric form of world history. This is a difficult task but a necessary one because, as the Dutch 
historian Johan Huizinga already wrote in the 1930s: 'our civilization is the first to have for its past, the past of the world, our history is the first to be world history'. ${ }^{11}$

\section{References}

1. Quoted in S. Avineri (ed) (1969) Karl Marx on Colonialism and Modernization (New York: Doubleday \& Co), pp. 11-12.

2. S. Avineri (ed) (1969) Karl Marx on Colonialism and Modernization (New York: Doubleday \& Co), p. 10.

3. G.W.F. Hegel (1944) The Philosophy of History (New York), p. 99.

4. A. Smith (1971) The Wealth of Nations (London/New York: Everyman's Library), p. 130.

5. E. Sik (1966) The History of Black Africa 2 vols (Budapest) Vol. I, p. 17.

6. H. R. Trevor-Roper (1965) The Rise of Christian Europe (London), p. 9.

7. S. Feierman (1995) Africa in history: the end of universal narratives. In Gyan Prakash (ed), After Colonialism, Imperial Histories and Post-Colonial Displacements (Princeton: Princeton University Press).

8. T. Ranger (1967) Towards a usable African past. In C. Fyfe (ed), African Studies since 1945: a Tribute to Basil Davidson (London), p. 17.

9. J. Nehru (1956) The Discovery of India (London), p. 28.

10. J. C. van Leur (1955) Indonesian Trade and Society. Essays in Asian Social and Economic History (The Hague) p. 261.

11. J. Huizinga (1936) A definition of the concept of history. In R. Klibansky and H.J. Paton (eds) Philosophy and History (Oxford) p. 8.

\section{About the Author}

H. L. Wesseling is a historian and Rector of the Netherlands Institute for Advanced Study and is also Deputy editor of the European Review. 